Article

\title{
Improving Fruit Quality, Bioactive Compounds, and Storage Life of Date Palm (Phoenix dactylifera L., cv. Barhi) Using Natural Elicitors
}

\author{
Zienab F. R. Ahmed ${ }^{1, *(\mathbb{D})}$, Fatima Y. Y. Al Shaibani ${ }^{1}$, Navjot Kaur ${ }^{1}{ }^{(\mathbb{D}}$, Sajid Maqsood ${ }^{2}$ \\ and Guillermo Schmeda-Hirschmann ${ }^{3}$ (D) \\ 1 Integrative Agriculture Department, College of Agriculture and Veterinary Medicine, \\ United Arab Emirates University, Al Ain P.O. Box 15551, United Arab Emirates; \\ 200919629@uaeu.ac.ae (F.Y.Y.A.S.); navjotkaur@uaeu.ac.ae (N.K.) \\ 2 Food Science Department, College of Agriculture and Veterinary Medicine, United Arab Emirates University, \\ Al Ain P.O. Box 15551, United Arab Emirates; sajid.m@uaeu.ac.ae \\ 3 Institute of Chemistry of Natural Resources, University of Talca, Casilla 747, Talca 3460000, Chile; \\ schmeda@utalca.cl \\ * Correspondence: zienab.ahmed@uaeu.ac.ae; Tel.: +971-5052-08360
}

check for

updates

Citation: Ahmed, Z.F.R.; Al Shaibani, F.Y.Y.; Kaur, N.; Maqsood, S.;

Schmeda-Hirschmann, G. Improving Fruit Quality, Bioactive Compounds, and Storage Life of Date Palm (Phoenix dactylifera L., cv. Barhi) Using Natural Elicitors. Horticulturae 2021, 7, 293. https://doi.org/10.3390/ horticulturae7090293

Academic Editor: Carmit Ziv

Received: 18 July 2021

Accepted: 28 August 2021

Published: 6 September 2021

Publisher's Note: MDPI stays neutral with regard to jurisdictional claims in published maps and institutional affiliations.

Copyright: (c) 2021 by the authors. Licensee MDPI, Basel, Switzerland. This article is an open access article distributed under the terms and conditions of the Creative Commons Attribution (CC BY) license (https:// creativecommons.org/licenses/by/ $4.0 /)$.

\begin{abstract}
Barhi" date fruit is highly appreciated and widely consumed at the Bisr stage (first edible stage) of maturity. However, maintaining its quality for long periods of time after harvest and throughout marketing is a substantial challenge. Therefore, the objective of this study was to investigate the effects of preharvest spray treatments of $1 \%$ chitosan $(\mathrm{Ch})$ in conjunction with $3 \%$ calcium chloride (Ca) and $2 \mathrm{mM}$ salicylic acid (SA) on "Barhi" fruit's shelf life, quality, and phytochemical composition at harvest and during cold storage. All treatments significantly delayed the ripening and decay of "Barhi" dates compared to controls. Ch treatment, followed by $\mathrm{Ch}+\mathrm{SA}$ and $\mathrm{Ch}+\mathrm{SA}+\mathrm{Ca}$, showed the lowest weight loss. $\mathrm{Ch}+\mathrm{Ca}, \mathrm{Ch}+\mathrm{SA}+\mathrm{Ca}$, and $\mathrm{Ch}+\mathrm{SA}$ treatments showed significantly lower levels of total soluble solids (TSS) compared to the control fruit. $\mathrm{Ch}+\mathrm{Ca}$ and $\mathrm{Ch}+\mathrm{Ca}+\mathrm{SA}$ treatments showed no decayed fruit after 60 days of cold storage. At the end of storage time, the $\mathrm{Ca}$ treatment, followed by $\mathrm{Ch}+\mathrm{Ca}+\mathrm{SA}$, showed the greatest total phenolic (TPC), flavonoids (TFC), and tannin (TTC) contents. $\mathrm{Ch}+\mathrm{SA}+\mathrm{Ca}, \mathrm{Ch}+\mathrm{SA}$, and $\mathrm{Ch}$ showed significantly higher antioxidant and antimicrobial activities compared to controls. Based on these findings, these treatments may be recommended to prolong the shelf life of "Barhi" date fruit.
\end{abstract}

Keywords: date palm; quality; preharvest; chitosan; fruit decay; storage life

\section{Introduction}

Date palm (Phoenix dactylifera L.) is grown in the dry and hot regions of North African countries and the Middle East [1]. It is also important for agriculture and economy in the Arab Gulf area. [2]. The fruit is high in dietary fibers, carbohydrates, proteins, vitamins, minerals, phenolic, tannins, and antioxidant compounds [1,3]. In Arabic terms, date fruit development and ripening stages are recognized as Hababouk, Kimri, Bisr (or Khalal), Rutab, and Tamer [4]. These stages describe cell division, unripe green (cell elongation), unripe full-colored, soft brown, and firm raisin-like fruit, respectively [5]. Generally, date fruit is harvested and brought to market at three stages - namely, Bisr, Rutab, and Tamer-depending on the cultivar (i.e., the fruit content of soluble tannins), climatic conditions, and market demands [6].

"Barhi" fruit (also known as Barhee, Barhy, or Berhi) are most widely consumed after they reach the Bisr stage (full-size, crunchy, colored, and mostly edible) of maturity, when they are crisp and sweet with a bright yellow appearance [7]. After harvesting, the fruit ripens rapidly into its advanced stage Rutab (second edible stage), and becomes softer, brown, sweeter, and eventually loses its market value [4]. These changes are consequences of the increasing respiration rate of living tissues, which leads to a high metabolic rate 
and, eventually, to fruit senescence [7]. As a climacteric fruit, the time from ripening to senescence in "Barhi" is very short, and ultimately leads to a huge market loss [6]. Therefore, slowing down the ripening process and senescence is critical for enhancing the fruit's marketability and shelf life [6].

Approaches such as controlled-atmosphere storage, modified-atmosphere packaging, and cold storage have been employed to reduce quality changes during the storage of date fruit [8-10]. Applications with natural elicitors have also been shown to induce physiological adaptations and defensive responses in plants [11,12]. In previous pre- and postharvest investigations, natural elicitors-i.e., chitosan, salicylic acid, etc.- - have been shown to delay tissue softening and ripening, improve quality, and increase fruit shelf life in different fruit crops [7,13]. Chitosan is a well-known natural elicitor because of its eliciting, antibacterial, and film-forming properties [12,13]; it has been reported to improve the quality and shelf life of several fruit and vegetable crops [13-16]. Another example of a natural elicitor is salicylic acid (SA) - a simple phenolic phytohormone with various roles in plant growth and development; it also has a potential role in preventing postharvest damage to vegetables and fruits $[6,16,17]$. In addition to chitosan and salicylic acid, calcium increases the stiffness of cell walls, thus delaying tissue softening and ripening $[18,19]$. Postharvest application of calcium chloride retains cell turgor, membrane integrity, and tissue firmness, and delays membrane lipid catabolism, thereby increasing the shelf life of fresh fruit [19-21]. The mechanism by which these elicitors exert their effects involves triggering the synthesis of phytochemicals and enhancing the production of particular antioxidant enzymes in vegetables and fruits, including "Barhi" date fruit $[11,13,14,19]$.

Regarding "Barhi" date fruit, to the best of our knowledge, there are no reports on the synergistic effects of different natural elicitors on "Barhi" fruit-particularly as preharvest spray treatments. As a result, the aim of this study was to investigate the synergistic effects of chitosan in combination with calcium chloride and/or salicylic acid on "Barhi" fruit's quality and phytochemical content at harvest, and for two months of cold storage.

\section{Materials and Methods}

\subsection{Plant Material and Sampling}

During the 2020 season, six date palm trees (Phoenix dactylifera L., cv. "Barhi") were randomly selected from the experimental farm of the College of Food and Agriculture at $\mathrm{Al}$ Foah, $\mathrm{Al}$ Ain, United Arab Emirates (UAE), located at the latitude and longitude coordinates of $24.2191^{\circ} \mathrm{N}$ and $55.7146^{\circ} \mathrm{E}$. Palm trees (20 years old) were drip-irrigated and subjected to regular agricultural practices. The trees were pruned to keep the leaf-to-bunch ratio at 8:1, and the number of female spathes per palm was adjusted to 8 . The design of the experiment was a complete random design with 6 palms (replicates); each palm received 7 different treatments (one treatment for each bunch). Each treatment was sprayed during three physiologically active stages of fruit development $(5,15$, and 18 weeks from pollination) with different elicitors as follows: control (deionized water), chitosan (1\%), SA (2 mM), Ca (3\%), Ch + Ca (1:1, v/v), Ch + SA (1:1, v/v), and Ch + SA + Ca (1:1:1, $v / v / v)$. The last spray application was two weeks before harvest. Date palm bunches were harvested at full maturity (Bisr stage); the whole fruit should be yellow, and the yellowish-green area should not exceed $10 \%$ on the bunch. Immediately after harvest, fruit were transported to the lab, cleaned, and sorted to obtain uniform fruit (fully yellow fruit at similar stages of development) to be analyzed. A total of 100 fruit from each treatment were randomly collected for initial analysis of their physical, physiochemical, phytochemical, and bioactive properties at harvest time. For storage, a group of 500 fruit from each treatment was collected and stored in perforated plastic bags (100 fruit per bag) at $2{ }^{\circ} \mathrm{C}$ and $90-92 \%$ relative humidity for a period of 60 days. Every 15 days, one bag of fruit was randomly withdrawn for analysis. The ripening/decaying fruit were counted, and then the fruit were immediately sliced and blinded. Three samples ( $10 \mathrm{~g}$ each) of mixed tissue were utilized for phytochemical analysis, and 10 grams were used to produce TSS juice. Another sample of 25 fruit was separately stored in perforated plastic bags for color 
and fruit weight loss measurement every two weeks. For microbiological analysis, samples of 25 fruit were aseptically collected in sterile bags and kept under the above conditions.

\subsection{Physiochemical Analysis}

\subsubsection{Fruit Physical Characteristics}

Fruit dimensions and weight were determined at harvest, as described by Rastegar et al. [22]. The weight loss of the fruit was measured once every 15 days during storage and reported as a percentage of the original weight before the cold storage, using the following equation:

Fruit weight loss $(\%)=($ Initial weight - Weight at specific interval $) /($ Initial weight $) \times 100$

\subsubsection{Fruit Ripening and Decay Percentage}

The fruit were visually inspected for ripening progress and decay every other week until complete decay of the fruit occurred during the storage period (60 days). The ripening (Rutab) was visually estimated by counting the ripe fruit (fruit that showed brown softening of $\sim 20 \%$ of their total area were considered ripe), and decay was visually estimated by counting the fruit with signs of fungal/bacterial growth on the surface; then, the percentage was calculated as described by Kumar et al. [23], using the following equations:

$$
\begin{aligned}
& \text { Rutab }(\%)=\text { "Number of Rutab fruit" / "Total number of fruit" } \times 100 \\
& \text { Decay }(\%)=\text { "Number of decay fruit" / "Total number of fruit" } \times 100
\end{aligned}
$$

\subsubsection{Total Soluble Solids (TSS)}

Ten grams of smashed fruit was mixed with ten milliliters of distilled water and blended. The blended juice was filtered and the clear juice was utilized. The TSS was determined as a percentage value in the juice using a digital refractometer (DR 6000, A. Kruss Optronic GmbH, Hamburg, Germany). The refractometer reading was multiplied by the dilution factor.

\subsubsection{Fruit Surface Color}

A Hunter Lab colorimeter (Hunter Lab Inc., Reston, VA, USA) was used to assess the surface color of the fruit. The color values of the fruit were represented as $L^{*}$ (brightness), $a^{*}$ (blue/yellow), and $b^{*}$ (red/green). These parameters were then used to determine the total color difference $\left(\Delta E^{*}\right)$, chroma $\left(C^{*}\right)$, and hue angle $\left(h^{\circ}\right)$, as follows:

$$
\begin{gathered}
\Delta E=\left[\left(L^{*}-L^{*} 0\right)+\left(a^{*}-a^{*} 0\right)+\left(b^{*}-b^{*} 0\right)\right]^{1 / 2} \\
C^{*}=\left(a^{* 2}+b^{* 2}\right)^{1 / 2} \\
h^{\circ}=180^{\circ}+\arctan \left(b^{*} / a^{*}\right)
\end{gathered}
$$

where $a^{*} 0, b^{*} 0$, and $L^{*} 0$ values represent control fruit [24].

\subsection{Determination of Total Microbial Count}

The microbiological examinations were carried out in the microbiological food laboratory. Total bacterial count as well as yeast and mold counts were determined for treated and untreated date fruit samples at harvest (day 0) and at the end of storage time (day 60). One gram of fruit tissue was aseptically mixed with nine milliliters of sterile peptone water under sterile conditions and used for serial dilutions of samples. The pour plate technique was utilized for preparing the plate count agar (PCA) and potato dextrose agar (PDA). PCA plates were incubated at $37^{\circ} \mathrm{C}$ for $48 \mathrm{~h}$, while PDA plates were incubated at $27^{\circ} \mathrm{C}$ for $5 \mathrm{~d}$. At the end of the incubation time, the number of colonies was recorded as $\log _{10}$ colony-forming unit per $\mathrm{g}$ of fresh weight $\left(\log _{10} \mathrm{CFU} \mathrm{g}{ }^{-1}\right)$. 


\subsection{Extraction of Bioactive Compounds}

Extraction of phenolic compounds was achieved by homogenizing $2 \mathrm{~g}$ of fresh fruit samples in $20 \mathrm{~mL}$ of $80 \%$ methanol using a water bath shaker (150 rpm) at $45{ }^{\circ} \mathrm{C}$ for $24 \mathrm{~h}$. Then, the samples were filtered using Whatman \#1 filter paper, and the supernatant (date extract) was utilized for further analysis.

\subsubsection{Phytochemical Analysis}

Total Phenolic Content

Date extract ( $100 \mu \mathrm{L}$ each) was added to tubes, followed by $50 \mu \mathrm{L}$ of Folin-Ciocalteu reagent, and mixed by vortexing. Then, the tubes were incubated at ambient temperature for $2 \mathrm{~min}$. Two milliliters of $\mathrm{NaOH}(6 \%)$ was added to each tube. Absorbance was measured at $750 \mathrm{~nm}$ using a spectrophotometer (Shimadzu, Kyoto, Japan). The total phenolic content (TPC) of samples was determined and recorded as mg of gallic acid equivalents (GAE) per $100 \mathrm{~g}$ of fresh weight (mg $100 \mathrm{~g}^{-1} \mathrm{GAE}$ ) using a standard curve obtained by measuring the absorbance of known concentrations of gallic acid [25].

\section{Total Flavonoid Content}

Total flavonoid content (TFC) was determined as described by Kim et al. [26], with some modifications. First, $75 \mu \mathrm{L}$ of $\mathrm{NaNO}_{2}(5 \%)$ was added to $250 \mu \mathrm{L}$ of date extract in a test tube and kept for $5 \mathrm{~min}$ in the dark. Then, $75 \mu \mathrm{L}$ of $\mathrm{AlCl}_{3}(10 \%)$ was added, and the mixture was vortexed and held in the dark for 6 min. Next, $500 \mu \mathrm{L}$ of $\mathrm{NaOH}(1 \mathrm{M})$ was added and mixed by vortexing. The volume was brought to $2.5 \mathrm{~mL}$ using distilled water. The absorbance was measured at $510 \mathrm{~nm}$ with a spectrophotometer (Shimadzu, Kyoto, Japan). The obtained results were reported as $\mathrm{mg}$ of catechin per $100 \mathrm{~g}$ of fresh weight (mg $100 \mathrm{~g}^{-1} \mathrm{CE}$ ).

\section{Total Tannin Content}

The total tannin content (TTC) in date extracts was determined as described by Bentebba et al. [27], with some modifications [19]. First, $1 \mathrm{~mL}$ of ethanol vanillin solution (4\%) and $0.2 \mathrm{~mL}$ of $\mathrm{HCl}(37 \%)$ were added to $0.4 \mathrm{~mL}$ of date extract or catechin (as standard). The mixture was vortexed and kept in the dark at ambient temperature for $15 \mathrm{~min}$ before measuring the absorbance of the pink color at $500 \mathrm{~nm}$ utilizing a spectrophotometer. The obtained results of total tannin were recorded as $\mathrm{mg}$ of catechin equivalents per $100 \mathrm{~g}$ of fresh weight (mg $\left.100 \mathrm{~g}^{-1} \mathrm{CE}\right)$.

\section{Antioxidant Activity}

Antioxidant activity was determined using the 2,2-diphenyl-1-picrylhydrazyl (DPPH) and 2,2'-azino-bis (3-ethylbenzothiazoline-6-sulfonic acid) diammonium salt (ABTS) radical scavenging activity assays, as described by Wu et al. and Arnao et al. [28,29], and modified by Ahmed et al. [19]

For the DPPH radical scavenging activity assay, $1.5 \mathrm{~mL}$ samples with concentrations ranging from 0.5 to $10 \mathrm{mg} \mathrm{L}^{-1}$ were mixed with $1.5 \mathrm{~mL}$ of $0.15 \mathrm{mM} \mathrm{DPPH}$ in $95 \%$ ethanol. The mixture was allowed to stand at room temperature, in the dark, for $30 \mathrm{~min}$. Using a spectrophotometer, the absorbance of the mixture was measured at $517 \mathrm{~nm}$. A sample blank for each concentration was made in the same way, except that ethanol was utilized in place of DPPH solution. $\mathrm{IC}_{50}$ values $\left(\mathrm{mg} \mathrm{mL}^{-1}\right)$ were calculated for each sample.

For the ABTS radical scavenging activity assay, the stock solutions were ABTS solution $(7.4 \mathrm{mM})$ and potassium persulfate solution $(2.6 \mathrm{mM})$. The working solution was made by combining equal parts of the two stock solutions and enabling them to react for 12 $\mathrm{h}$ at ambient temperature in the dark. The solution was further diluted by combining 1 $\mathrm{mL}$ of ABTS solution with $50 \mathrm{~mL}$ of methanol, yielding an absorbance of $1.1 \pm 0.02$ units at $734 \mathrm{~nm}$ as measured with a spectrophotometer. For each assay, a fresh ABTS solution was made. Samples $(150 \mu \mathrm{L})$ with concentrations ranging from 0.5 to $10 \mathrm{mg} \mathrm{mL}^{-1}$ were combined with $2850 \mu \mathrm{L}$ of ABTS solution and left at room temperature for $2 \mathrm{~h}$ in the dark. 
The absorbance was then measured at $734 \mathrm{~nm}$. A sample blank for each concentration was made in the same way, except that methanol was utilized in place of ABTS solution. A Trolox standard curve ranging from 50 to $600 \mu \mathrm{M}$ was generated. The activity was recorded as $\mathrm{mg}$ of Trolox equivalents (TE) per $100 \mathrm{~g}$ of fresh weight (mg $100 \mathrm{~g}^{-1} \mathrm{TE}$ ).

\subsection{Statistical Analysis}

All physical, physiochemical, microbiological, and phytochemical data collected form the complete random design were statistically analyzed by analysis of variance ANOVA using SAS statistical software (SAS Institute Inc., 2000, Cary, NC, USA). The results were presented as means \pm standard errors (SE) of the means. Comparisons between means were carried out using the least significant differences (LSDs) at $p \leq 0.05$ to compare the means of each treatment between different storage times, and between treatments within the storage time point. Correlation coefficients between physical and biochemical characteristics of fruits were also estimated using SAS.

\section{Results and Discussion}

\subsection{Physical Quality Parameters of "Barhi" Fruit at Harvest}

Table 1 shows the average length, width, and weight of "Barhi" fruit at harvest. When affected by treatments with preharvest elicitors, treated "Barhi" fruit exhibited significant variations in physical characteristics. The average length, width, and weight were significantly $(p \leq 0.05)$ greater in SA-, $\mathrm{Ch}+\mathrm{Ca}_{-}$, and $\mathrm{Ch}+\mathrm{SA}$-treated fruits compared to controls and other treatments. These enhancements in fruit dimensions could be attributable to the impact of SA in conjunction with other elicitors in preserving cellular integrity and boosting the strength of carbohydrate sink, improving the size and weight of the fruit [30]. Moreover, Mohamed et al. [6] reported that preharvest spray treatment with SA significantly improved "Barhi" fruit's length, width, and weight relative to control fruit. Fresh fruit's physical quality parameters are critical, since they directly reflect the physical impact of the used elicitors. The current results reveal that using SA and $\mathrm{Ch}$ alone or in conjunction with $\mathrm{Ca}$ and $\mathrm{Ch}$ has significant effects on the "Barhi" fruit's physical qualities.

Table 1. Effects of preharvest application of natural elicitors on "Barhi" date fruit's physical properties at harvest.

\begin{tabular}{cccc}
\hline Treatment & Fruit Weight (g) & Fruit Width $(\mathbf{m m})$ & Fruit Length $(\mathbf{m m})$ \\
\hline Control & $9.44 \pm 0.91^{\mathrm{b}}$ & $30.56 \pm 1.02^{\mathrm{bc}}$ & $22.60 \pm 0.73^{\mathrm{a}}$ \\
Ch & $9.73 \pm 0.46^{\mathrm{ab}}$ & $30.49 \pm 0.81^{\mathrm{c}}$ & $22.01 \pm 0.56^{\mathrm{ab}}$ \\
Ca & $8.91 \pm 0.65^{\mathrm{b}}$ & $29.69 \pm 1.11^{\mathrm{c}}$ & $21.86 \pm 0.85^{\mathrm{b}}$ \\
SA & $10.46 \pm 0.81^{\mathrm{a}}$ & $31.58 \pm 1.2^{\mathrm{b}}$ & $23.13 \pm 1.02^{\mathrm{a}}$ \\
Ch + SA & $10.03 \pm 0.32^{\mathrm{a}}$ & $34.59 \pm 0.92^{\mathrm{a}}$ & $23.84 \pm 0.99^{\mathrm{a}}$ \\
Ch + Ca & $10.61 \pm 0.80^{\mathrm{a}}$ & $32.11 \pm 1.30^{\mathrm{b}}$ & $23.55 \pm 0.89^{\mathrm{a}}$ \\
Ch + SA + Ca & $8.46 \pm 0.22^{\mathrm{b}}$ & $29.19 \pm 0.90^{\mathrm{c}}$ & $20.81 \pm 1.03^{\mathrm{b}}$ \\
\hline
\end{tabular}

Values are the mean $(\mathrm{n}=25) \pm$ SE. Means with the same letter(s) in the same column are not significantly different at $p \leq 0.05$ using the LSD test. Ch: chitosan; SA: salicylic acid; Ca: calcium chloride.

\subsection{Fruit Weight Loss during Storage}

Figure 1 illustrates the percentage of weight loss in "Barhi" fruit over 60 days of cold storage at $2{ }^{\circ} \mathrm{C}$ and $90-92 \%$ RH. According to the results, the use of elicitors had a significant impact on "Barhi" fruit's weight. During storage, weight loss occurred steadily in all fruits, to various degrees. Significant variations $(p \leq 0.05)$ in weight loss were observed across treatments when compared to the controls (Figure 1). At day 60, the smallest weight loss was observed in Ch-treated fruit, followed by $\mathrm{Ch}+\mathrm{SA}, \mathrm{Ch}+\mathrm{SA}+\mathrm{Ca}, \mathrm{SA}, \mathrm{Ch}+\mathrm{Ca}, \mathrm{Ca}$, and control, with, 9.4, 10.4, 10.8, 10.8, 12.0, 13.1, and 14.1\%, respectively (Figure 1). 


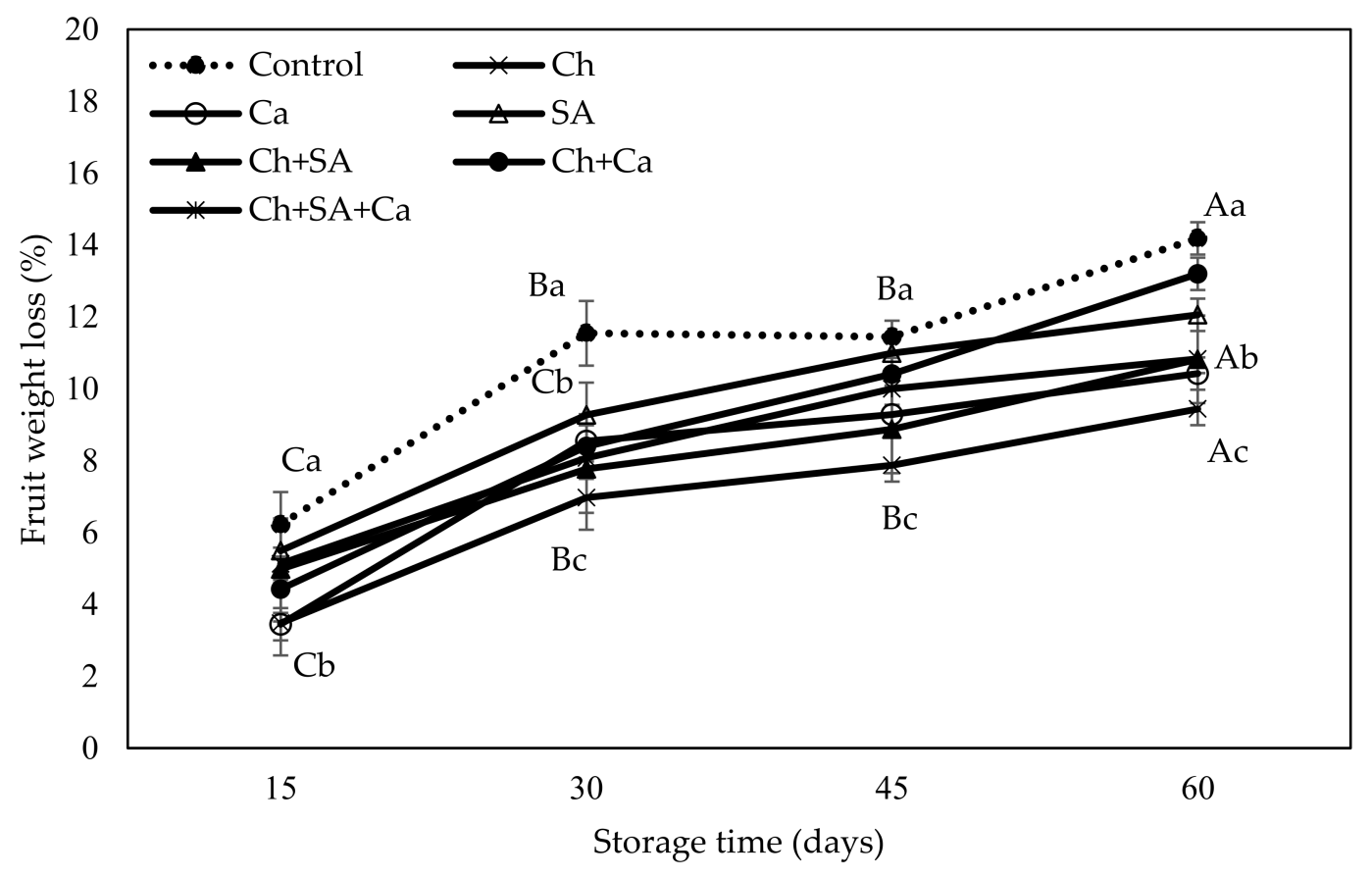

Figure 1. Effect of preharvest application of natural elicitors on weight loss percentage of "Barhi" fruit during cold storage for two months; values are the mean $(n=25) \pm$ SE. The LSD test at $p \leq 0.05$ was used to compare the means between treatments. Means with the same letter(s) between treatments within storage time intervals (small letter) and at different time intervals (capital letter) are not significantly different. Ch: chitosan; SA: salicylic acid; Ca: calcium chloride.

The minimal weight loss seen in fruits sprayed with chitosan alone might be due to the film-forming characteristics of chitosan, which greatly reduces the rate of water evaporation from the fruit, as observed with other chitosan-treated fruits [31-33]. Furthermore, as compared to SA, Ca had significantly $(p \leq 0.05)$ smaller weight loss. According to Atia et al. [34], pre-storage treatment with Ca decreased weight loss in "Barhi" dates better than SA. In addition, Mohamed et al. [6] found that preharvest treatment with SA decreased weight loss during storage in treated "Barhi" fruit compared to controls. SA is widely recognized for its ability to minimize chilling damage, decrease ripening, and resist different abiotic and biotic stressors [35]; this may suggest that fruit treated with SA has a better physiological state-most likely due to a lower respiration rate, which can also be related to enhanced fruit turgidity. Weight loss is a major factor that affects the shelf life and marketability of harvested fruits [6,30]; it occurs as a result of the increase in respiration rate and/or moisture loss from the fruit during storage [6,36,37].

According to the findings of this study, the weight loss reduction observed in fruit treated with $\mathrm{Ch}$ alone, or in conjunction with $\mathrm{Ca}$ and SA, signifies that the treated fruit had better physiological conditions, most likely as a result of a reduction in transpiration and respiration rates, as well as the regulating influence of these elicitors on the ripening process. In addition, the capacity of $\mathrm{Ch}$ to form a film, which creates a barrier to gas exchanges, reduces respiration, and decrease fruit weight loss [13].

\subsection{Total Soluble Solids (TSS)}

The results of TSS concentration at harvest (day 0 ) and during cold storage at $2{ }^{\circ} \mathrm{C}$ for 60 days are presented in Figure 2. Significant differences $(p \leq 0.05)$ were observed between different treatments in relation to TSS concentration. In all fruits, the concentration of TSS increased steadily with ripening throughout the storage time. At harvest, and after 60 days of cold storage, the control fruit showed the greatest TSS concentration (from 30 to $42 \%$ ), followed by Ch-treated fruit (from 30 to $41 \%$ ). The lowest TSS concentration was observed with Ca-treated fruit (from $26 \%$ to $36 \%$ ); this result might be attributable to the high $\mathrm{Ca}(3 \%)$ concentration in this treatment. Likewise, $\mathrm{Ch}+\mathrm{Ca}-, \mathrm{Ch}+\mathrm{SA}+\mathrm{Ca}-$, and $\mathrm{Ch}+\mathrm{SA}$-treated 
fruit showed significantly $(p \leq 0.05)$ lower concentrations of TSS relative to the control fruit after 15, 30, 45, and 60 days of storage (Figure 2). These data are compatible with the weight reduction results shown in Figure 1, and are supported by the positive correlation seen in Table 2. Similarly, Kassem et al. [30] reported comparable TSS concentrations in SA-treated "Barhi" fruit. However, Mohamed et al. [6] found no significant difference $(p \leq 0.05)$ in TSS concentrations between the control and SA-treated "Barhi" fruit.

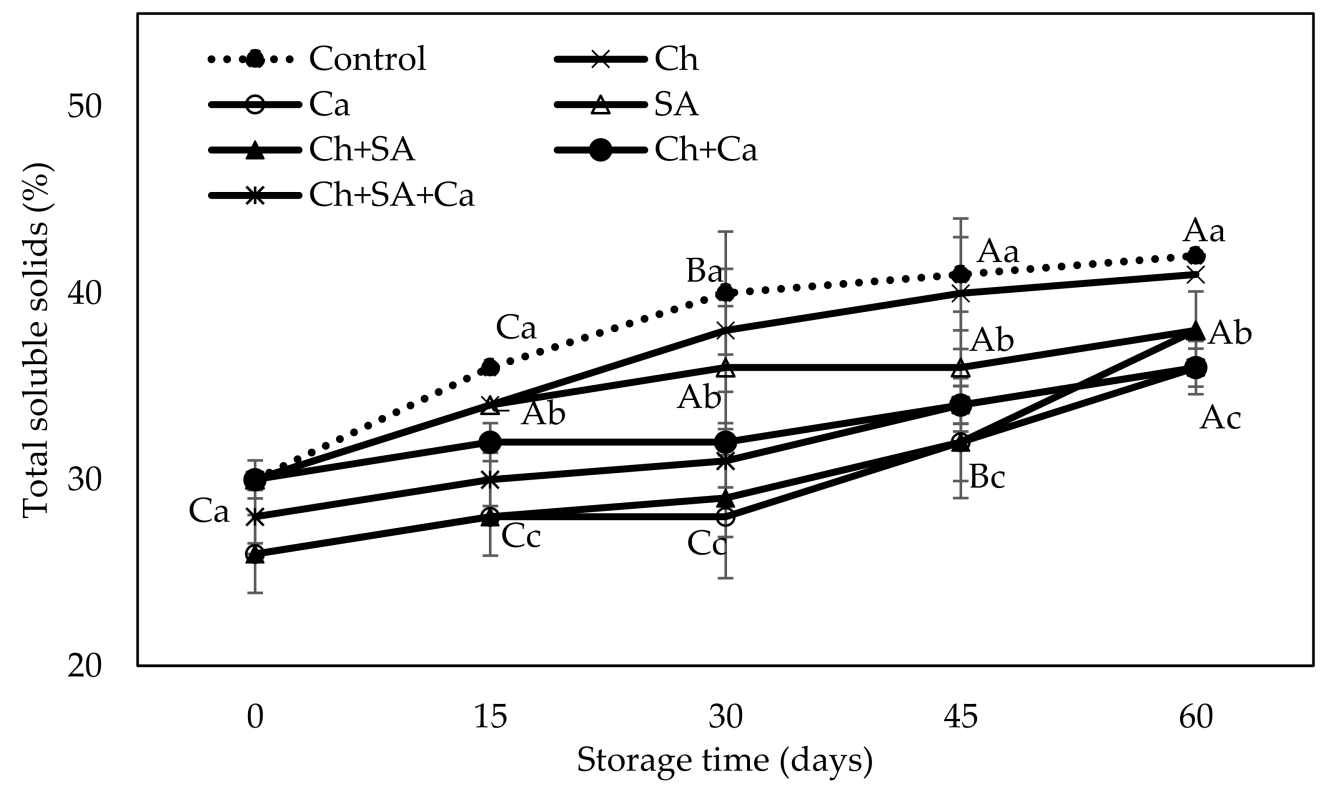

Figure 2. Effects of preharvest treatments with natural elicitors on "Barhi" fruit's total soluble solids during cold storage for two months; values are the mean $(n=3) \pm S E$. Means with the same letter(s) between treatments within storage time intervals (small letter) and at different time intervals (capital letter) are not significantly different. Ch: chitosan; SA: salicylic acid; Ca: calcium chloride.

Table 2. Pearson's correlation coefficients between some physical and biochemical properties of "Barhi" fruit. TPC: total phenolic content; TSS: total soluble solids.

\begin{tabular}{|c|c|c|c|c|c|c|c|c|}
\hline Traits & TSS & TPC & Rutab \% & Decay \% & $\begin{array}{l}\text { Weight } \\
\text { Loss \% }\end{array}$ & $L^{*}$ & $\Delta E$ & $C^{*}$ \\
\hline TPC & $-0.72^{* * *}$ & & & & & & & \\
\hline Rutab\% & $0.72 * * *$ & $-0.93^{* * *}$ & & & & & & \\
\hline Decay\% & $0.60^{* * *}$ & $-0.44^{* * *}$ & $0.54 * * *$ & & & & & \\
\hline $\begin{array}{l}\text { Weight } \% \\
\text { loss }\end{array}$ & $0.51^{* * *}$ & $-0.79 * * *$ & $0.68^{* * *}$ & $0.44^{* * *}$ & & & & \\
\hline$L^{*}$ & $-0.67^{* * *}$ & $0.85^{* * *}$ & $-0.91^{* * *}$ & $-0.39 * * *$ & $-0.60 * * *$ & & & \\
\hline$\Delta E$ & $0.66^{* * *}$ & $-0.80 * * *$ & $0.89 * * *$ & $0.46^{* * *}$ & $0.57^{* * *}$ & $-0.98 * * *$ & & \\
\hline$C^{*}$ & $-0.61^{* * *}$ & $0.72 * * *$ & $-0.83^{* * *}$ & $-0.48^{* * *}$ & $-0.53^{* * *}$ & $0.94^{* * *}$ & $-0.96^{* * *}$ & \\
\hline$h^{\circ}$ & $-0.69^{* * *}$ & $0.82^{* * *}$ & $-0.88^{* * *}$ & $-0.53^{* * *}$ & $-0.62^{* * *}$ & $0.93^{* * *}$ & $-0.92^{* * *}$ & $0.90^{* * *}$ \\
\hline
\end{tabular}

Generally, the formation of smaller sugars by the breakdown of larger polysaccharide molecules via enzymatic actions and loss of moisture throughout storage are accountable for the increased TSS during storage [6,38]. Additionally, the efficacy of elicitors has been reported to be controlled by the response of the fruit tissues, which decreases as the fruit ripens [13]. As per our results, Ca alone or in conjunction with $\mathrm{Ch}$ and SA delays polysaccharide breakdown, leading to lower TSS levels in treated "Barhi" fruit and, hence, a slower rate of maturation and ripening, while maintaining the fruit's quality.

\subsection{Fruit Color Characteristics}

Significant color parameters-namely, $L^{*}, h^{\circ}, \Delta E$, and $C^{*}$ - were determined in order to detect color changes in the fruit throughout the cold storage (Figure 3). Overall, color parameters were significantly $(p \leq 0.05)$ affected by elicitor treatments. Additionally, color 
values steadily declined in all fruits with the increase in storage time, with the exception of Ca-treated fruit, which showed the lowest color change values. In all fruits, $L^{*}$ values decreased as storage progressed, indicating a substantial decline in fruit lightness. At day 60 , the lowest decrease in $L^{*}$ was detected in fruit treated with $\mathrm{Ca}$, followed by $\mathrm{Ch}+\mathrm{SA}$ and $\mathrm{Ch}+\mathrm{Ca}+\mathrm{SA}$, compared to other treatments and controls (Figure 3). When compared to other treatments, including controls, the same treatments showed smaller $\Delta \mathrm{E}$ values, with $\mathrm{Ch}+\mathrm{Ca}$ displaying the greatest $\Delta E$. Likewise, by the end of the storage period, Ca-treated fruit had the highest $C^{*}$ values, followed by $\mathrm{Ch}+\mathrm{SA}$ - and $\mathrm{Ch}+\mathrm{Ca}+\mathrm{SA}$ treated fruits, whereas $\mathrm{Ch}+\mathrm{Ca}$ showed the opposite pattern. The latter treatment contains calcium - which could also be responsible for delaying ripening progress and change in color-as well as chitosan, which forms a thin film that delays gas exchanges and slows the metabolism. The $L^{*}, h^{\circ}$, and $C^{*}$ values show positive correlation with rising TSS in Table 2 and Figure 3, while $\Delta \mathrm{E}$ shows the opposite. The observed delay in the color change in fruits treated with Ca could be due to influence of $\mathrm{Ca}$ on ethylene activity, which could unmask chlorophyll pigment and lower the respiration rate of the fruit, thus slowing the color change [20]. Accordingly, SA- and Ch-treated pistachio fruit showed better color values relative to controls [39].

Color is an important visual characteristic of food-especially fresh fruit-and it can affect product appeal and acceptance [40]. As a result, the influence of treatments on the color of fresh "Barhi" fruit was considered in the current study. Damaging color reactions-particularly enzymatic ones-are a naturally occurring phenomenon produced mostly by the activities of polyphenol oxidase and peroxidase throughout the ripening and storage of fruit, and have been associated with a decrease in fruit market value [41,42]. These reactions have been attributed to the oxidation of phenolic constituents and the formation of dark brown pigments in date fruits [41]. Given the current results, it is likely that applying $\mathrm{Ca}$ alone or in conjunction with $\mathrm{SA}$ and $\mathrm{Ch}$ delayed color change reactions in fresh "Barhi" fruit to different degrees.

\subsection{Total Phenolic Content (TPC) of Fruit at Harvest and during Storage}

Figure 4 shows the TPC content in "Barhi" fruit at harvest and during the course of cold storage time. The type of elicitor used significantly $(p \leq 0.05)$ impacted the TPC content at harvest and during the period of cold storage. Overall, TPC progressively declined in all fruits with the increase in storage time. Ca-treated fruit showed the greatest TPC content, which gradually declined from $445.7 \mathrm{mg} 100 \mathrm{~g}^{-1} \mathrm{GAE}$ at day 0 to $260.66 \mathrm{mg}$

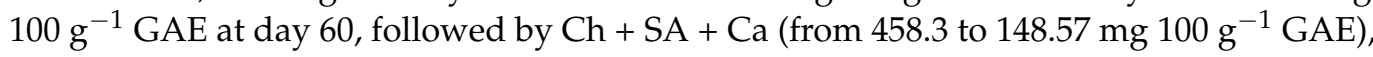
in comparison with other treatments, including controls. However, several studies have revealed differences in TPC concentrations between different date cultivars (50-400 mg 100 $\mathrm{g}^{-1}$ ) [4-6,41], which could be due to cultivar differences and/or environmental variables. In general, in different date cultivars, the concentration of phenols decreases over time from the early stages of growth to maturity and ripening [41].

Because of its capacity to stimulate antioxidant systems and heat shock proteins, SA has previously been demonstrated to reduce chilling damage in peach fruit during cold storage [43]. The use of elicitors-i.e., chitosan, $\mathrm{Ca}$, and SA-has been shown to increase the content of polyphenolic compounds in fruits and, thus, improve their quality [14]. The present study reveals that the continuous decline observed in TPC during storage (Figure 4 ) is positively correlated with the decrease in color parameters-such as $L^{*}, h^{\circ}$, and $C^{*}$-while the opposite is true of $\Delta E$ (Table 2 and Figure 3), in all fruits, at various levels. According to these findings, preharvest $\mathrm{Ch}+\mathrm{SA}+\mathrm{Ca}$ treatment enhances TPC levels, improving the quality and shelf life of "Barhi" fruit. 

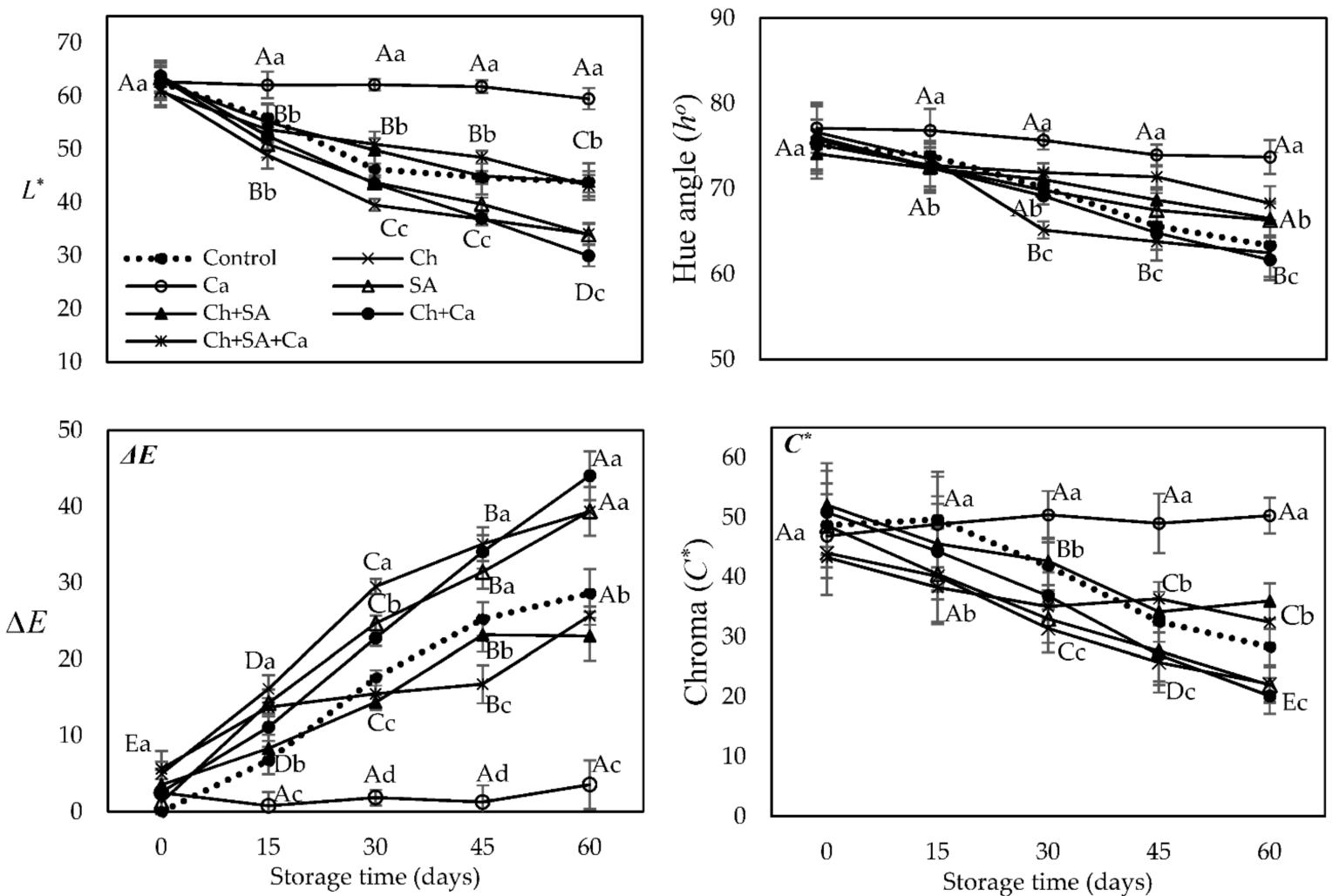

Figure 3. Effects of preharvest treatments with natural elicitors on "Barhi" fruit's color during cold storage for two months; values are the mean $(\mathrm{n}=25) \pm \mathrm{SE}$. The LSD test at $p \leq 0.05$ was used to compare the means between treatments. Means with the same letter(s) between treatments within storage time intervals (small letter) and at different time intervals (capital letter) are not significantly different. Ch: chitosan; SA: salicylic acid; Ca: calcium chloride.

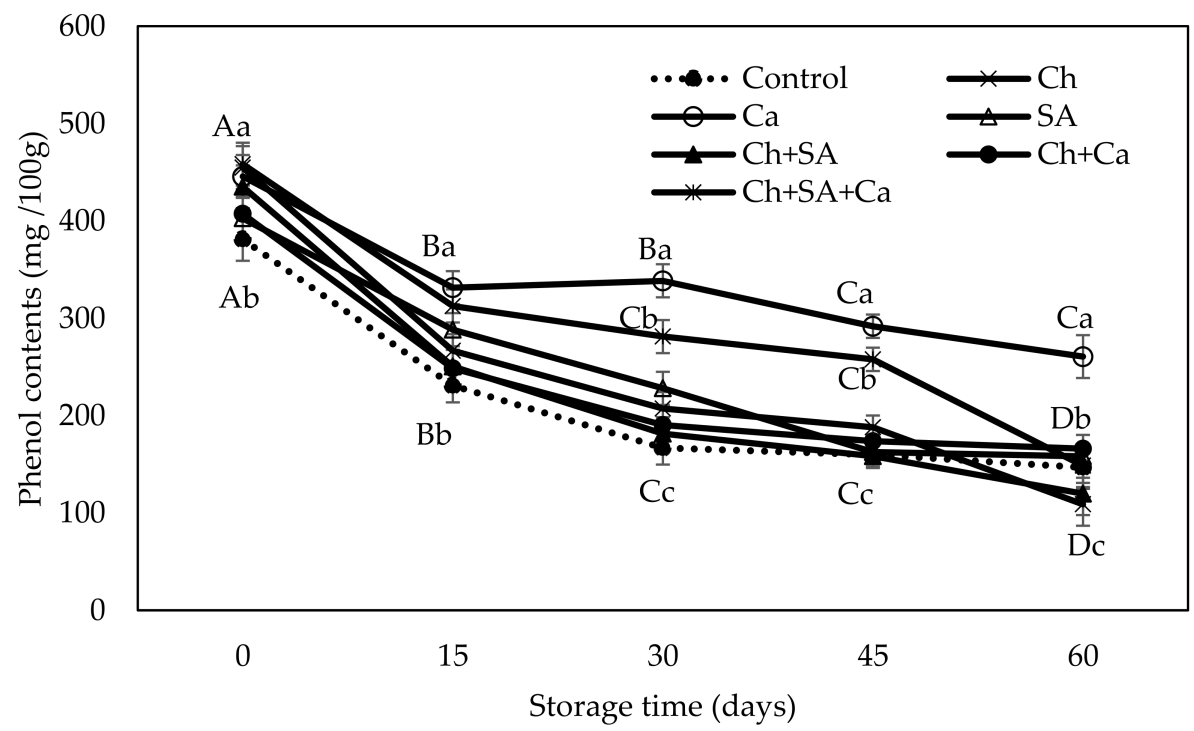

Figure 4. Effects of preharvest application of natural elicitors on the total phenol content of "Barhi" fruit during cold storage for two months; values are the mean $(\mathrm{n}=3) \pm \mathrm{SE}$. The LSD test at $p \leq 0.05$ was used to compare the means between treatments. Means with the same letter(s) between treatments within storage time intervals (small letter) and at different time intervals (capital letter) are not significantly different. Ch: chitosan; SA: salicylic acid; Ca: calcium chloride. 


\subsection{Total Flavonoids, Tannins, and Antioxidant Activity at Harvest}

At harvest, the effects of applied elicitors on total flavonoid content (TFC), total tannin content (TTC), and antioxidant activity were investigated (Table 3). Significant variations $(p \leq 0.05)$ between different treatments in TFC, TTC, and antioxidant activity were observed to be affected by the applied elicitors. In comparison to all treatments,

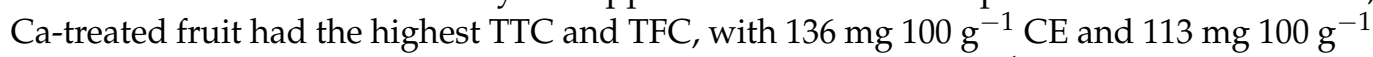
$\mathrm{CE}$, respectively, followed by $\mathrm{CH}+\mathrm{SA}\left(130\right.$ and $105 \mathrm{mg} 100 \mathrm{~g}^{-1} \mathrm{CE}$, respectively), $\mathrm{CH}$ (126 and $105 \mathrm{mg} 100 \mathrm{~g}^{-1} \mathrm{CE}$, respectively), and $\mathrm{CH}+\mathrm{SA}+\mathrm{Ca}\left(120\right.$ and $107 \mathrm{mg} 100 \mathrm{~g}^{-1}$ $\mathrm{CE}$, respectively), whereas $\mathrm{CH}+\mathrm{Ca}$-treated fruit had lower TTC and TFC (114 and $89 \mathrm{mg}$ $100 \mathrm{~g} \mathrm{CE}$, respectively), but was not significantly different compared to controls. Based on this finding, the $\mathrm{CH}+\mathrm{Ca}$ treatment had some influence on TTC and TFC in treated fruit, meriting further investigation. Regarding antioxidant activity, $\mathrm{CH}+\mathrm{SA}+\mathrm{Ca}$-treated

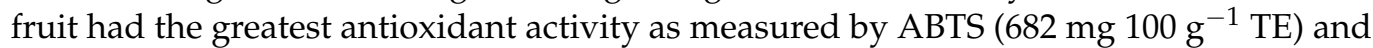
$\mathrm{DPPH}\left(\mathrm{IC}_{50}=2.1 \mathrm{mg} \mathrm{mL}^{-1}\right)$ radical scavenging activity assays (Table 3$)$. The lower $\mathrm{IC}_{50}$ numbers in the DPPH radical scavenging activity assay measurements indicated a 50\% reduction in the extract concentration required to scavenge the DPPH radical, signifying an increase in antioxidant activity. Comparable results were reported by Mohamed et al. [6], who observed that preharvest spraying with SA significantly $(p \leq 0.05)$ improved DPPH scavenging activity in "Barhi" fruit relative to control fruit. Preharvest spraying of chitosan enhanced phenolic compounds and flavonoids up to 2.6-fold in strawberries compared to controls [15]. Furthermore, it was reported that the use of SA increased the levels of antioxidant compounds in table grapes [17].

Table 3. Effects of preharvest application of natural elicitors on phytochemical contents and antioxidant activity of "Barhi" fruit at harvest.

\begin{tabular}{|c|c|c|c|c|}
\hline Treatments & $\begin{array}{c}\text { Tannin } \\
\left(\mathrm{mg} 100 \mathrm{~g}^{-1} \mathrm{CE}\right)\end{array}$ & $\begin{array}{c}\text { Flavonoids } \\
\left(\mathrm{mg} 100 \mathrm{~g}^{-1} \mathrm{CE}\right)\end{array}$ & $\begin{array}{c}\text { ABTS } \\
\left(\mathrm{mg} 100 \mathrm{~g}^{-1} \mathrm{TE}\right)\end{array}$ & $\begin{array}{c}\mathrm{IC}_{50} \\
\left(\mathrm{mg} \mathrm{mL}^{-1}\right)\end{array}$ \\
\hline Control & $108.73 \pm 5.92^{d}$ & $88.32 \pm 1.32^{c}$ & $338.45 \pm 2.72^{f}$ & $3.60 \pm 0.34^{b}$ \\
\hline $\mathrm{Ch}$ & $126.55 \pm 6.81^{b}$ & $105.91 \pm 2.28^{b}$ & $427.63 \pm 3.11^{\mathrm{e}}$ & $3.26 \pm 0.54^{d}$ \\
\hline $\mathrm{Ca}$ & $136.17 \pm 5.23^{a}$ & $113.81 \pm 1.05^{\mathrm{a}}$ & $638.61 \pm 3.98^{b}$ & $3.00 \pm 0.21^{\mathrm{d}}$ \\
\hline SA & $118.63 \pm 6.41^{\mathrm{cd}}$ & $84.52 \pm 1.18^{\mathrm{d}}$ & $610.26 \pm 2.89^{c}$ & $3.66 \pm 0.12^{b}$ \\
\hline $\mathrm{Ch}+\mathrm{SA}$ & $130.06 \pm 5.67^{\mathrm{a}}$ & $105.92 \pm 1.76^{b}$ & $633.85 \pm 3.05^{b c}$ & $3.77 \pm 0.32^{\mathrm{a}}$ \\
\hline $\mathrm{Ch}+\mathrm{Ca}$ & $114.27 \pm 6.31^{\mathrm{d}}$ & $89.11 \pm 1.92^{c}$ & $537.64 \pm 4.21^{\mathrm{d}}$ & $3.49 \pm 0.21^{c}$ \\
\hline $\mathrm{Ch}+\mathrm{SA}+\mathrm{Ca}$ & $120.25 \pm 4.87^{c}$ & $107.13 \pm 2.31^{b}$ & $682.05 \pm 4.96^{\mathrm{a}}$ & $2.10 \pm 0.40^{\mathrm{e}}$ \\
\hline
\end{tabular}

Values are the mean $(\mathrm{n}=3) \pm$ SE. Means with the same letter(s) in the same column are not significantly different at $p \leq 0.05$ using the LSD test. Ch: chitosan; SA: salicylic acid; Ca: calcium chloride.

These results are consistent with the small Rutab percentage (low ripening) and $0 \%$ decay noticed with the $\mathrm{CH}+\mathrm{SA}+\mathrm{Ca}$ treatment (Figures 5 and 6). In general, the concentrations of antioxidants in dates decrease as they move from the early developmental stage (Bisr) to the ripening stages (Rutab and Tamer) [41]. These findings are in line with those obtained for TPC at harvest (Figure 4), suggesting that phenolic compounds play a critical role in the antioxidant capacity of "Barhi" fruit. In addition, a positive connection between antioxidant compound concentrations and antioxidant capability has been reported in five date cultivars, including the "Barhi" date [41]. 


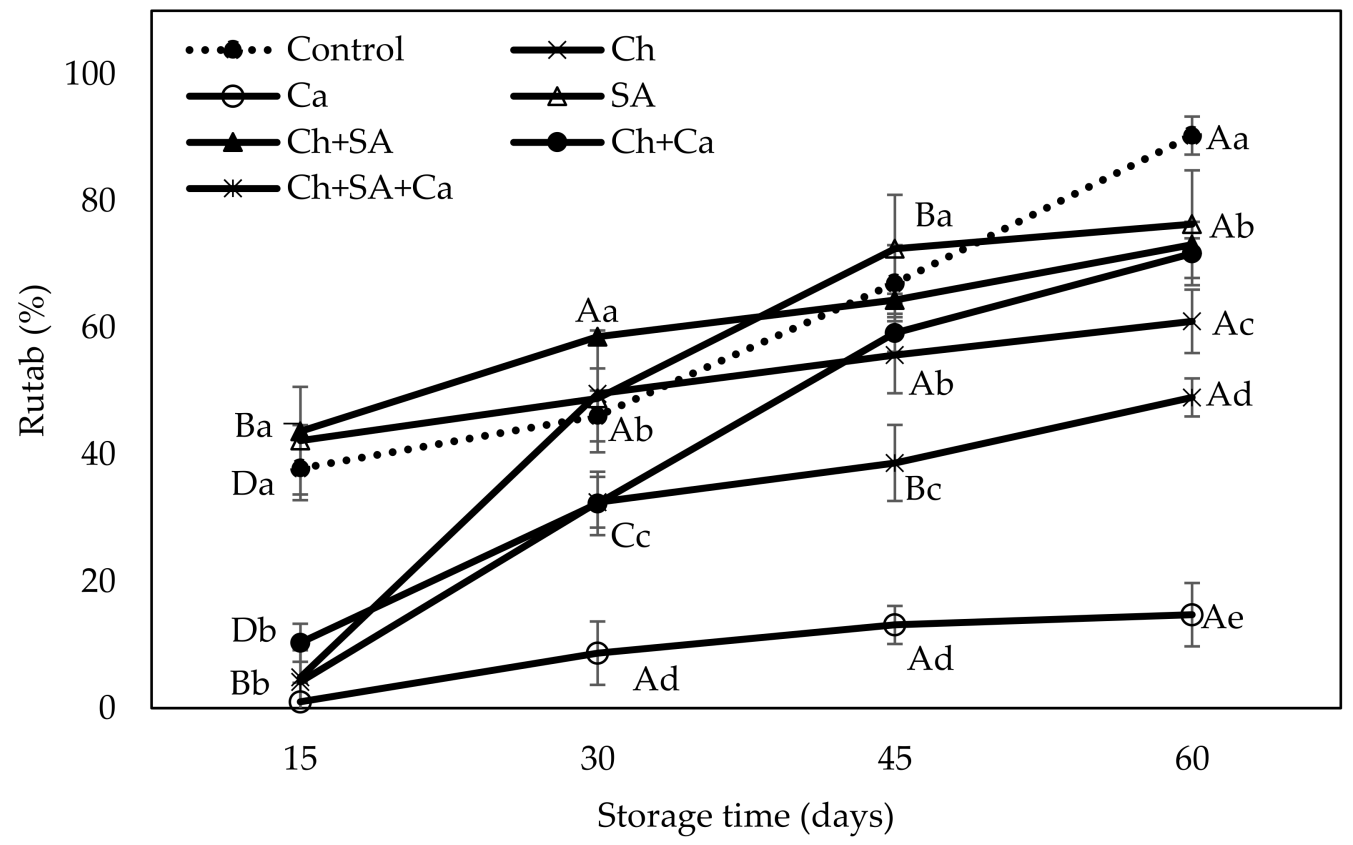

Figure 5. Effects of preharvest application of natural elicitors on "Barhi" fruit's ripening percentage during cold storage for two months; values are the mean $(n=25) \pm$ SE. The LSD test at $p \leq 0.05$ was used to compare the means between treatments. Means with the same letter(s) between treatments within storage time intervals (small letter) and at different time intervals (capital letter) are not significantly different. Ch: chitosan; SA: salicylic acid; Ca: calcium chloride.

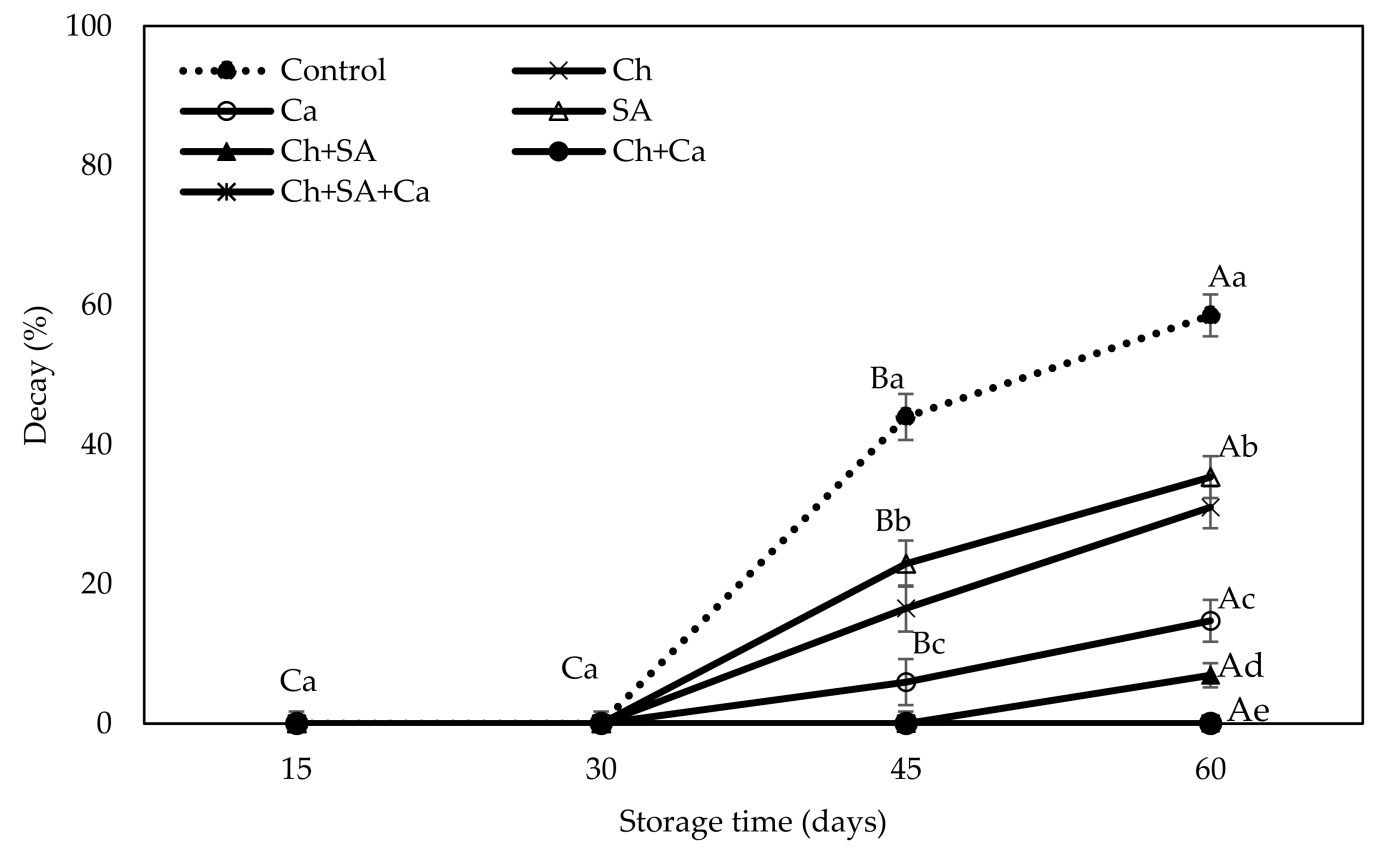

Figure 6. Effects of preharvest application of natural elicitors on "Barhi" fruit's decay percentage during cold storage for two months; values are the mean $(n=25) \pm$ SE. The LSD test at $p \leq 0.05$ was used to compare the means between treatments. Means with the same letter(s) between treatments within storage time intervals (small letter) and at different time intervals (capital letter) are not significantly different. Ch: chitosan; SA: salicylic acid; Ca: calcium chloride.

As a climacteric fruit, oxidative stress in date fruit is thought to be responsible for the decrease in antioxidant components (Figure 4) during ripening, as a result of the decline in free radical scavenging capability [6]. The formation of extra reactive oxygen species (ROS) such as superoxides and $\mathrm{H}_{2} \mathrm{O}_{2}$ may emerge and be implicated in the ripening and senescence of the date fruit, as reported with other fruits [44]. According to these findings, 
applying $\mathrm{Ch}+\mathrm{SA}+\mathrm{Ca}$ before harvest boosted the amount of antioxidant compounds, which improved quality and shelf life, most likely by reducing the abundance of damaging radicals.

\subsection{Fruit Ripening}

Figure 5 shows the results of fruit ripening during 60 days of cold storage at $2{ }^{\circ} \mathrm{C}$. As compared to the controls, all treatments significantly $(p \leq 0.05)$ delayed fruit ripening during cold storage. Rutab percentage increased steadily during the cold storage period in all treatments, to different degrees (Figure 5). By the end of the storage period, the greatest Rutab percentage was observed in the control fruit, followed by SA-, Ch + SA-, Ch + Ca-, Ch-, $\mathrm{Ch}+\mathrm{SA}+\mathrm{Ca}-$, and Ca-treated fruit, with 90.3, 76.3, 73.1, 71.7, 61.0, 49.0, and 14.7\%, respectively.

These results are consistent with the TSS results depicted in Figure 2, where the same treatments showed lower TSS content compared to other treatments, including controls. Additionally, the Rutab percentage showed a positive correlation with the increase in weight loss and TSS (Table 2).

These findings might be regarded as evidence of elicitors decreasing "Barhi" fruit's ripening during cold storage. Preharvest treatment with SA also slowed the ripening of "Barhi" fruit by three weeks as compared to control fruit [30]. In addition, the capacity of Ch to form a film, which creates a barrier to gas exchanges and reduces respiration, can also delay fruit ripening. It is worth noting that a less ripe fruit is less likely to be exposed to postharvest rot [13]. Moreover, calcium treatment is well recognized for slowing respiration and delaying ripening in fruits $[20,21,36]$. The present results reveal the delaying impact of $\mathrm{Ch}, \mathrm{SA}$, and $\mathrm{Ca}$ in various combinations on fruit maturation and ripening in comparison to controls. Fruit ripening is a biological process that causes membrane impermeability and, ultimately, senescence as a result of membrane components' oxidation [5,45]. Ethylene is believed to play a major role in ripening and senescence processes [30,46]; as a result, it is possible that sprayed elicitors reduce fruit ripening by controlling ethylene production or activity (decline of Rutab occurrence in date fruit). However, date fruit maturation is not an asynchronous phenomenon in all date fruits in the same bunch, since fruit at varying stages of differentiation can be found in the same bunch at any given time. Bisr fruits that received the same treatment, for example, may reach the Rutab stage at different periods in the same bunch. Thus, there are several significant biological differences between individual fruits [6]. As a result, substantial inherent biological variations between individual fruits within the same bunch may be responsible for certain discrepancies.

\subsection{Fruit Decay}

Figure 6 shows the percentage of fruit decay during 60 days of cold storage. All preharvest spray treatments significantly $(p \leq 0.05)$ decreased the occurrence of fruit decay during cold storage compared to controls, to different degrees. The decay began after 28 days of cold storage, and progressed throughout the storage period-with the exception of the $\mathrm{Ch}+\mathrm{Ca}$ and $\mathrm{Ch}+\mathrm{Ca}+\mathrm{SA}$ treatments, which showed $0 \%$ decay after 60 days of cold storage (Figure 6). Among all the treatments, and after 60 days of storage, the control treatment showed the highest decay percentage, with $58 \%$, followed by the $\mathrm{SA}, \mathrm{Ch}, \mathrm{Ca}$, and $\mathrm{Ch}+\mathrm{SA}$ treatments with $35,31,14$, and $7 \%$ decay, respectively (Figure 6).

The results might be attributed to the protective effect of the applied elicitors. Similarly, Gomes et al. [17] found that SA at concentrations of 1 and $2 \mathrm{mmol} \mathrm{L}^{-1}$ was effective in decreasing grapes' berry decay. Ca and AS, alone or in conjunction, delayed strawberry fruit' softening, resulting in less decay [47]. The use of elicitors such as SA, Ca, and oxalic acid has been shown to stimulate defensive response and reduce rotting in other fruits $[16,48,49]$. In the present study, the $\mathrm{Ch}+\mathrm{SA}+\mathrm{Ca}$-treated fruit underwent no decay throughout the cold storage period (Figure 6), while the lowest Rutab percentage was found after Ca treatment (Figure 5). Additionally, there was a negative correlation between TPC and weight loss, decay, and Rutab\%, indicating that TPC plays an essential role in the 
ripening and senescence of date fruit. The results of this study show that applying $\mathrm{Ch}$ in conjunction with $\mathrm{Ca}$ and SA could protect "Barhi" fruit from decay for a long period during cold storage, most likely via activating the fruit's defense mechanisms, resistance responses of fruit tissue, and/or inhibition of the development of decay-causing pathogens [13]. The high TPC in the fruit as a result of the slow ripening following $\mathrm{Ch}+\mathrm{SA}$ treatment could be related to the reduced respiration rate, weight loss, and decay incidence, as well as the positive influence on TSS [16].

\subsection{Microbiological Quality of Fruit}

Figure 7 shows the microbial counts $\left(\log _{10} \mathrm{CFU} \mathrm{g}{ }^{-1}\right)$ on "Barhi" fruit samples at harvest and by the end of the cold storage time. Overall, fungal/mold counts (FMCs) and total bacterial counts (TBCs) exhibited significant differences $(p \leq 0.05)$ at harvest and at the end of the storage period, showing the impact of elicitor treatments. When compared to controls and other treatments, "Barhi" fruits treated with $\mathrm{Ch}, \mathrm{SA}, \mathrm{Ch}+\mathrm{Ca}$, and $\mathrm{Ch}+$ $\mathrm{Ca}+\mathrm{SA}$ showed lower TBCs at day 0, while FMCs in $\mathrm{Ch}$ - and $\mathrm{Ch}+\mathrm{Ca}+\mathrm{SA}$-treated fruits were significantly $(p \leq 0.05)$ lower than in other treatments, including controls. At day 60, $\mathrm{Ch}+\mathrm{Ca}+\mathrm{SA}$-treated fruits, followed by $\mathrm{Ch}+\mathrm{AS}-$ and Ch-treated fruits, had lower TBCs relative to controls and other treatments, while the lowest FMCs were observed in the $\mathrm{Ch}$ and $\mathrm{Ch}+\mathrm{Ca}$ treatments (Figure 7).

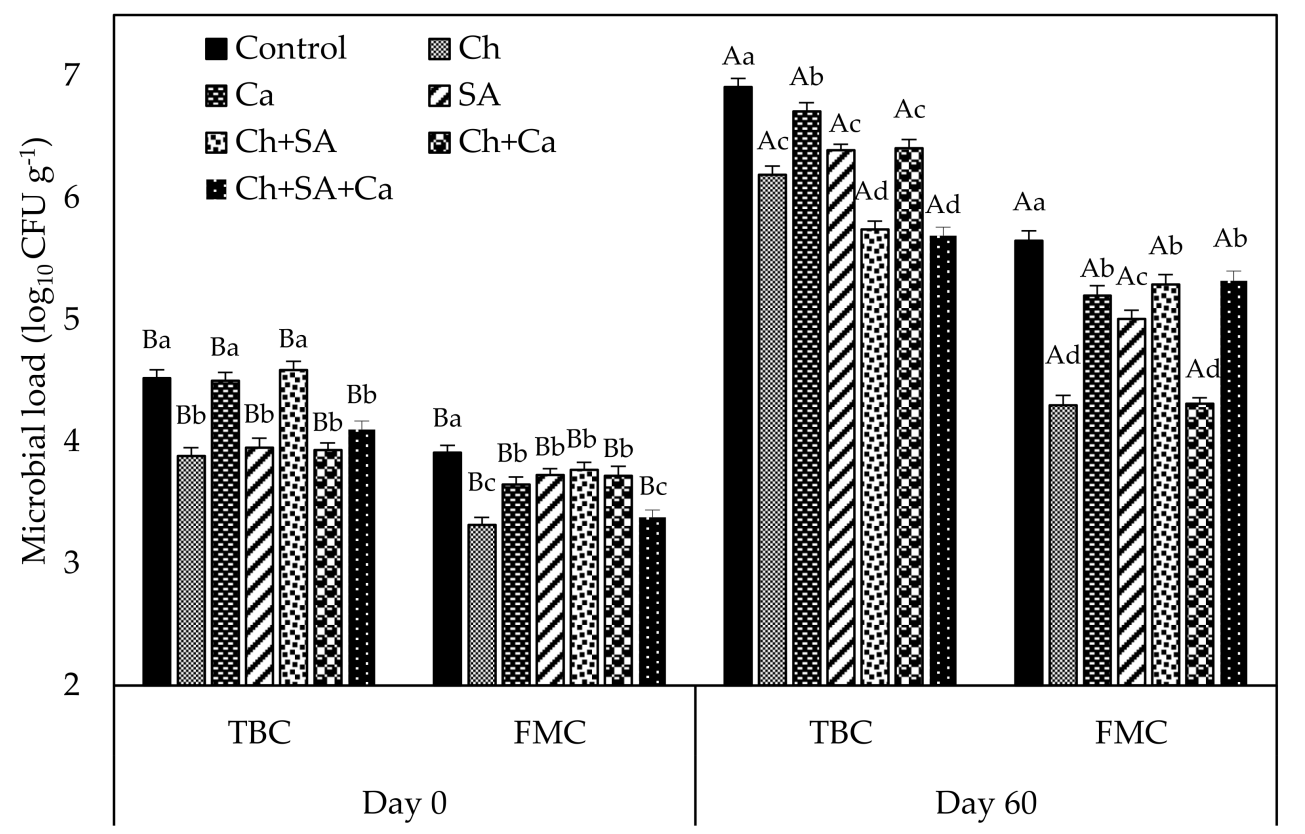

Figure 7. Effects of preharvest application of natural elicitors on microbial counts ( $\log _{10} \mathrm{CFU} \mathrm{g}^{-1}$ ) on "Barhi" date fruits during cold storage for two months; values are the mean $(n=3) \pm$ SE. The LSD test at $p \leq 0.05$ was used to compare the means between treatments. Means with the same letter(s) between treatments within storage time intervals (small letter) and at different time intervals (capital letter) are not significantly different. Ch: chitosan; SA: salicylic acid; Ca: calcium chloride.

Among the various elicitors, SA showed the best results in inducing defensive reactions and minimizing decay in pear fruits [49]. Chitosan has also been proven to boost plants' defenses against bacteria and fungi, among other pathogens [13]. Furthermore, either alone or in combination, the $\mathrm{Ch}$ and SA treatments significantly decreased the growth of fungi and bacteria in pistachio fruits [39]. According to the current findings, $\mathrm{Ch}+\mathrm{SA}+\mathrm{Ca}$ had a greater antimicrobial impact than the other treatments, including controls. The same treatment had the lowest percentage of decay, as well as the greatest antioxidant activity, which could explain these microbial results (Figure 6 and Table 3). Accordingly, increasing phenols and antioxidant activity via the application of various 
elicitors, separately or in combination, may trigger defensive mechanism(s) that lead to disease resistance and an increase in "Barhi" fruit's shelf life, as has been observed in other fruits $[13,48,50]$.

\section{Conclusions}

The results of this study show that using different elicitor combinations enhances the biochemical properties of fresh "Barhi" fruit during maturity and storage. Comparing the combinations of the elicitor treatments, $\mathrm{Ch}+\mathrm{Ca}$ - and $\mathrm{Ch}+\mathrm{Ca}+\mathrm{SA}$-treated fruit showed no decay even after 60 days of storage. The $\mathrm{Ca}$ treatment, followed by $\mathrm{Ch}+\mathrm{Ca}+\mathrm{SA}$, exhibited the greatest TPC and postponed the fruit ripening during cold storage. When compared to other treatments, $\mathrm{Ch}+\mathrm{SA}$ showed the highest antibacterial and antioxidant activities, followed by the $\mathrm{Ch}+\mathrm{SA}+\mathrm{Ca}$ and $\mathrm{Ch}$ treatments. Based on these observations, it is possible that the delayed ripening and reduced fruit decay were due to the impact of the sprayed elicitors on the ripening process, thereby decreasing "Barhi" fruit's senescence. Accordingly, the $\mathrm{Ch}+\mathrm{SA}+\mathrm{Ca}$ and $\mathrm{Ch}+\mathrm{SA}$ combinations of elicitors may be recommended for large-scale application. Furthermore, this eco-friendly approach using combinations of natural elicitors could be a more effective, reasonable, and sustainable way to improve "Barhi" date fruit's quality. Additionally, since no immediate-type allergic reactions to chitosan-based treatments have been reported, it is unlikely that these treatments would affect consumers' preferences towards "Barhi" fruit.

Author Contributions: Conceptualization, Z.F.R.A.; methodology, Z.F.R.A.; investigation, F.Y.Y.A.S. and N.K.; data curation, Z.F.R.A.; writing—original draft preparation, F.Y.Y.A.S. and N.K.; writingreview and editing, Z.F.R.A.; review and editing, S.M. and G.S.-H.; supervision, Z.F.R.A.; funding acquisition, Z.F.R.A. All authors have read and agreed to the published version of the manuscript.

Funding: This research was funded by United Arab Emirates University (UAEU), project grant number G00003332.

Institutional Review Board Statement: Not applicable.

Informed Consent Statement: Not applicable.

Acknowledgments: The authors are grateful to UAEU for funding this project. Our gratitude is also extended to the College of Agriculture and Veterinary Medicine, Integrative Agriculture Department, Horticulture lab, and Food Science lab for assisting with the sample analysis.

Conflicts of Interest: The authors declare no conflict of interest.

\section{References}

1. Al-Alawi, R.A.; Al-Mashiqri, J.H.; Al-Nadabi, J.S.M.; Al-Shihi, B.I.; Baqi, Y. Date Palm Tree (Phoenix dactylifera L.): Natural products and therapeutic options. Front. Plant Sci. 2017, 8, 845. [CrossRef] [PubMed]

2. Gantait, S.; El-Dawayati, M.M.; Panigrahi, J.; Labrooy, C.; Verma, S.K. The retrospect and prospect of the applications of biotechnology in Phoenix dactylifera L. Appl. Microbiol. Biotechnol. 2018, 102, 8229-8259. [CrossRef] [PubMed]

3. Bentrad, N.; Hamida-Ferhat, A. Date palm fruit (Phoenix dactylifera): Nutritional values and potential benefits on health. In The Mediterranean Diet, 2nd ed.; Preedy, V.R., Watson, R.R., Eds.; Academic Press: Cambridge, MA, USA, 2020; pp. $239-255$.

4. Al-Qurashi, A.D.; Awad, M.A. Quality characteristics of bisir 'Barhee' dates during cold storage as affected by postharvest dipping in gibberellic acid, naphthaleneacetic acid and benzyladenine. Fruits 2011, 66, 343-352. [CrossRef]

5. Awad, M.A.; Al-Qurashi, A.D.; Mohamed, S.A. Biochemical changes in fruit of an early and a late date palm cultivar during development and ripening. Int. J. Fruit Sci. 2011, 11, 167-183. [CrossRef]

6. Mohamed, S.A.; Awad, M.A.; Al-Qurashi, A.D. Antioxidant activity, antioxidant compounds, antioxidant and hydrolytic enzymes activities of 'Barhee' dates at harvest and during storage as affected by pre-harvest spray of some growth regulators. Sci. Hortic. 2014, 167, 91-99. [CrossRef]

7. Abu-Shama, H.S.; Abou-Zaid, F.O.F.; El-Sayed, E.Z. Effect of using edible coatings on fruit quality of Barhi date cultivar. Sci. Hortic. 2020, 265, 109262. [CrossRef]

8. Aleid, S.; Saikhan, M. Effect of permeable modified atmosphere packaging on quality and shelf life of fresh Khenaizy dates stored at low temperature. J. Food Nutr. Res. 2017, 5, 503-509.

9. Alhamdan, A.M.; Elkhair, D.O.; Ehmed, K.A. Modeling of respiration rate of fresh date fruits (Barhi cultivar) under aerobic conditions. J. Adv. Agric. Technol. 2015, 2, 120-124. [CrossRef] 
10. Alsawmahi, O.N.; Al-Juhaimi, F.; Alhamdan, A.M.; Ghafoor, K.; Adiamo, O.Q.; Mohamed Ahmed, I.A.; Hassan, B.H.; Ehmed, K.A.; Babiker, E.E.; Abdelkarim, D. Phenolic, tannin, antioxidant, color, and sensory attributes of Barhi date (Phoenix dactylifera) fruit stored in modified atmosphere packages. J. Food Biochem. 2018, 42, e12576. [CrossRef]

11. Baenas, N.; García-Viguera, C.; Moreno, D.A. Elicitation: A tool for enriching the bioactive composition of foods. Molecules 2014, 19, 13541-13563. [CrossRef]

12. Moreno-Escamilla, J.O.; Alvarez-Parrilla, E.; de la Rosa, L.A.; Núñez-Gastélum, J.A.; González-Aguilar, G.A.; Rodrigo-García, J. Effect of elicitors in the nutritional and sensorial quality of fruits and vegetables. In Preharvest Modulation of Postharvest Fruit and Vegetable Quality; Siddiqui, M.W., Ed.; Academic Press: Cambridge, MA, USA, 2018; pp. 71-91.

13. Romanazzi, G.; Feliziani, E.; Sivakumar, D. Chitosan, a biopolymer with triple action on postharvest decay of fruit and vegetables: Eliciting, antimicrobial and film-forming properties. Front. Microbiol. 2018, 9, 2745. [CrossRef]

14. Ruiz-García, Y.; Gómez-Plaza, E. Elicitors: A tool for improving fruit phenolic content. Agriculture 2013, 3, 33-52. [CrossRef]

15. Rahman, M.; Mukta, J.A.; Sabir, A.A.; Gupta, D.R.; Mohi-Ud-Din, M.; Hasanuzzaman, M.; Miah, M.G.; Rahman, M.; Islam, M.T. Chitosan biopolymer promotes yield and stimulates accumulation of antioxidants in strawberry fruit. PLoS ONE 2018, 13, e0203769. [CrossRef] [PubMed]

16. Shen, Y.; Yang, H. Effect of preharvest chitosan-g-salicylic acid treatment on postharvest table grape quality, shelf life, and resistance to Botrytis cinerea-induced spoilage. Sci. Hortic. 2017, 224, 367-373. [CrossRef]

17. Gomes, E.P.; Vanz Borges, C.; Monteiro, G.C.; Filiol Belin, M.A.; Minatel, I.O.; Junior, A.P.; Tecchio, M.A.; Lima, G.P.P. Preharvest salicylic acid treatments improve phenolic compounds and biogenic amines in 'Niagara Rosada' table grape. Postharvest Biol. Technol. 2021, 176, 111505. [CrossRef]

18. Nirupama, P.; Gol, N.B.; Rao, T.R. Effect of post harvest treatments on physicochemical characteristics and shelf life of tomato (Lycopersicon esculentum Mill.) fruits during storage. Am. Eurasian J. Agric. Environ. Sci. 2010, 9, 470-479.

19. Ahmed, Z.F.R.; Alblooshi, S.S.N.A.; Kaur, N.; Maqsood, S.; Schmeda-Hirschmann, G. Synergistic Effect of Preharvest Spray Application of Natural Elicitors on Storage Life and Bioactive Compounds of Date Palm (Phoenix dactylifera L., cv. Khesab). Horticulturae 2021, 7, 145. [CrossRef]

20. Irfan, P.K.; Vanjakshi, V.; Prakash, M.N.K.; Ravi, R.; Kudachikar, V.B. Calcium chloride extends the keeping quality of fig fruit (Ficus carica L.) during storage and shelf-life. Postharvest Biol. Technol. 2013, 82, 70-75. [CrossRef]

21. Sohail, M.; Ayub, M.; Khalil, S.A.; Zeb, A.; Ullah, F.; Afridi, S.R.; Ullah, R. Effect of calcium chloride treatment on post harvest quality of peach fruit during cold storage. Int. Food Res. J. 2015, 22, 2225-2229.

22. Rastegar, S.; Rahemi, M.; Baghizadeh, A.; Gholami, M. Enzyme activity and biochemical changes of three date palm cultivars with different softening pattern during ripening. Food Chem. 2012, 134, 1279-1286. [CrossRef]

23. Kumar, D.; Mishra, D.S.; Chakraborty, B.; Kumar, P. Pericarp browning and quality management of litchi fruit by antioxidants and salicylic acid during ambient storage. J. Food Sci. 2013, 50, 797-802. [CrossRef]

24. Maskan, M. Kinetics of colour change of kiwifruits during hot air and microwave drying. J. Food Eng. 2001, 48, 169-175. [CrossRef]

25. Velioglu, Y.S.; Mazza, G.; Gao, L.; Oomah, B.D. Antioxidant activity and total phenolics in selected fruits, vegetables, and grain products. J. Agric. Food Chem. 1998, 46, 4113-4117. [CrossRef]

26. Kim, D.O.; Chun, O.K.; Kim, Y.J.; Moon, H.Y.; Lee, C.Y. Quantification of polyphenolics and their antioxidant capacity in fresh plums. J. Agric. Food Chem. 2003, 51, 6509-6515. [CrossRef] [PubMed]

27. Bentebba, F.Z.; Zineb, G.; Saidi, M.; Bensaci, C. Effects of development and ripening stage on phytochemical compositions, antioxidant and antibacterial activities of date palm fruits. Asian J. Chem. 2020, 32, 415-419. [CrossRef]

28. Wu, H.C.; Chen, H.M.; Shiau, C.Y. Free amino acids and peptides as related to antioxidant properties in protein hydrolysates of mackerel (Scomber austriasicus). Food Res. Int. 2003, 36, 949-957. [CrossRef]

29. Arnao, M.B.; Cano, A.; Acosta, M. The hydrophilic and lipophilic contribution to total antioxidant activity. Food Chem. 2001, 73, 239-244. [CrossRef]

30. Kassem, H.; Alobeed, R.; Ahmed, M. Extending harvest season, improving fruit quality and shelf life of 'Barhee' date palm by preharvest sprays. Acta Hortic. 2010, 882, 147-154. [CrossRef]

31. Petriccione, M.; De Sanctis, F.; Pasquariello, M.S.; Mastrobuoni, F.; Rega, P.; Scortichini, M.; Mencarelli, F. The effect of chitosan coating on the quality and nutraceutical traits of sweet cherry during postharvest life. Food Bioproc. Technol. 2015, 8, 394-408. [CrossRef]

32. Petriccione, M.; Mastrobuoni, F.; Pasquariello, M.S.; Zampella, L.; Nobis, E.; Capriolo, G.; Scortichini, M. Effect of chitosan coating on the postharvest quality and antioxidant enzyme system response of strawberry fruit during cold storage. Foods 2015, 4, 501-523. [CrossRef]

33. Romanazzi, G.; Feliziani, E.; Santini, M.; Landi, L. Effectiveness of postharvest treatment with chitosan and other resistance inducers in the control of storage decay of strawberry. Postharvest Biol. Technol. 2013, 75, 24-27. [CrossRef]

34. Atia, A.; Abdelkarim, D.; Younis, M.; Alhamdan, A. Effects of pre-storage dipping in calcium chloride and salicylic acid on the quality attributes of stored Khalal Barhi dates. Int. J. Agri. Bio. Eng. 2020, 13, 206-212. [CrossRef]

35. Ennab, H.A.; El-Shemy, M.A.; Alam-Eldein, S.M. Salicylic acid and putrescine to reduce post-harvest storage problems and maintain quality of Murcott Mandarin fruit. Agronomy 2020, 10, 115. [CrossRef]

36. Atia, A.; Abdelkarim, D.; Younis, M.; Alhamdan, A. Effects of calcium chloride and salicylic acid postharvest treatments on the quality of Khalal Barhi dates at different ripening levels during cold storage. J. Food Meas. Charact. 2018, 12, 1156-1166. [CrossRef] 
37. Shiri, M.A.; Bakhshi, D.; Ghasemnezhad, M.; Dadi, M.; Papachatzis, A.; Kalorizou, H. Chitosan coating improves the shelf life and postharvest quality of table grape (Vitis vinifera) cultivar Shahroudi. Turkish J. Agric. For. 2013, 37, 148-156.

38. Hazbavi, I.; Khoshtaghaza, M.H.; Mostaan, A.; Banakar, A. Effect of postharvest hot-water and heat treatment on quality of date palm (cv. Stamaran). J. Saudi Soc. Agric. Sci. 2015, 14, 153-159. [CrossRef]

39. Molamohammadi, H.; Pakkish, Z.; Akhavan, H.R.; Saffari, V.R. Effect of salicylic acid incorporated chitosan coating on shelf life extension of fresh In-Hull Pistachio fruit. Food Bioproc. Technol. 2020, 13, 121-131. [CrossRef]

40. FernÁndez-VÁzquez, R.; Stinco, C.M.; MelÉndez-MartÍnez, A.J.; Heredia, F.J.; Vicario, I.M. Visual and instrumental evaluation of orange juice color: A consumers'preference study. J. Sens. Stud. 2011, 26, 436-444. [CrossRef]

41. Awad, M.A.; Al-Qurashi, A.D.; Mohamed, S.A. Antioxidant capacity, antioxidant compounds and antioxidant enzyme activities in five date cultivars during development and ripening. Sci. Hortic. 2011, 129, 688-693. [CrossRef]

42. Mortazavi, S.M.H.; Azizollahi, F.; Moallemi, N. Some quality attributes and biochemical properties of nine iranian date (Phoenix dactylifera L.) cultivars at different stages of fruit development. Int. J. Hort. Sci. Technol. 2015, 2, 161-171.

43. Wang, L.; Chen, S.; Kong, W.; Li, S.; Archbold, D.D. Salicylic acid pretreatment alleviates chilling injury and affects the antioxidant system and heat shock proteins of peaches during cold storage. Postharvest Biol. Technol. 2006, 41, 244-251. [CrossRef]

44. Ferrer, A.; Remón, S.; Negueruela, A.I.; Oria, R. Changes during the ripening of the very late season spanish peach cultivar calanda: Feasibility of using CIELAB coordinates as maturity indices. Sci. Hortic. 2005, 105, 435-446. [CrossRef]

45. Ahmed, Z.F.R.; Palta, J.P. A Postharvest dip treatment with lysophosphatidylethanolamine, a natural phospholipid, may retard senescence and improve the shelf life of banana fruit. HortScience 2015, 50, 1035. [CrossRef]

46. Ahmed, Z.F.R.; Palta, J.P. Postharvest dip treatment with a natural lysophospholipid plus soy lecithin extended the shelf life of banana fruit. Postharvest Biol. Technol. 2016, 113, 58-65. [CrossRef]

47. Shafiei, M.; Karimi, K.; Taherzadeh, M.J. Palm date fibers: Analysis and enzymatic hydrolysis. Int. J. Mol. Sci. 2010, 11, 4285-4296. [CrossRef]

48. Wang, Y.Y.; Li, B.Q.; Qin, G.Z.; Li, L.; Tian, S.P. Defense response of tomato fruit at different maturity stages to salicylic acid and ethephon. Sci. Hortic. 2011, 129, 183-188. [CrossRef]

49. Tian, S.; Wan, Y.; Qin, G.; Xu, Y. Induction of defense responses against Alternaria rot by different elicitors in harvested pear fruit. Appl. Microbiol. Biotechnol. 2006, 70, 729-734. [CrossRef]

50. Sathiyabama, M.; Akila, G.; Charles, R.E. Chitosan-induced defence responses in tomato plants against early blight disease caused by Alternaria solani (Ellis and Martin) Sorauer. Arch. Phytopathol. Plant Protect. 2014, 47, 1963-1973. [CrossRef] 